\title{
Innate Immune System Response to Burn Damage-Focus on Cytokine Alteration
}

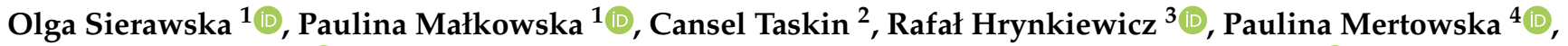 \\ Ewelina Grywalska ${ }^{4} \mathbb{D}$, Tomasz Korzeniowski ${ }^{5,6}$, Kamil Torres ${ }^{5,6}$, Agnieszka Surowiecka ${ }^{6}$, \\ Paulina Niedźwiedzka-Rystwej ${ }^{3, *(1)}$ and Jerzy Strużyna ${ }^{6,7}$
}

Citation: Sierawska, O.; Małkowska, P.; Taskin, C.; Hrynkiewicz, R.; Mertowska, P.; Grywalska, E.; Korzeniowski, T.; Torres, K.; Surowiecka, A.;

Niedźwiedzka-Rystwej, P.; et al. Innate Immune System Response to Burn Damage-Focus on Cytokine Alteration. Int. J. Mol. Sci. 2022, 23, 716. https://doi.org/10.3390/ ijms23020716

Academic Editor: Joseph Barbi

Received: 4 November 2021

Accepted: 7 January 2022

Published: 10 January 2022

Publisher's Note: MDPI stays neutral with regard to jurisdictional claims in published maps and institutional affiliations.

Copyright: (c) 2022 by the authors Licensee MDPI, Basel, Switzerland This article is an open access article distributed under the terms and conditions of the Creative Commons Attribution (CC BY) license (https:// creativecommons.org/licenses/by/ $4.0 /)$
1 Doctoral School of the University of Szczecin, Institute of Biology, University of Szczecin, 71-412 Szczecin, Poland; olga.sierawska@phd.usz.edu.pl (O.S.); paulina.malkowska@phd.usz.edu.pl (P.M.)

2 Biology Department, Faculty of Science, Ankara University, Ankara 06560, Turkey; canseltaskinn@hotmail.com

3 Institute of Biology, University of Szczecin, 71-412 Szczecin, Poland; rafal.hrynkiewicz@usz.edu.pl

4 Department of Experimental Immunology, Medical University of Lublin, 20-093 Lublin, Poland; paulinamertowska@umlub.pl (P.M.); ewelina.grywalska@gmail.com (E.G.)

5 Chair and Department of Didactics and Medical Simulation, Medical University of Lublin, 20-093 Lublin, Poland; tomasz.korzeniowski@umlub.pl (T.K.); kamil.torres@umlub.pl (K.T.)

6 East Center of Burns Treatment and Reconstructive Surgery, ul. Krasnystawska 52, 21-010 Łęczna, Poland; dr.surowiecka@gmail.com (A.S.); jerzy.struzyna@umlub.pl (J.S.)

7 Chair and Department of Plastic, Reconstructive Surgery and Burn Treatment, Medical University of Lublin, 20-093 Lublin, Poland

* Correspondence: paulina.niedzwiedzka-rystwej@usz.edu.pl

\begin{abstract}
In the literature, burns are understood as traumatic events accompanied by increased morbidity and mortality among affected patients. Their characteristic feature is the formation of swelling and redness at the site of the burn, which indicates the development of inflammation. This reaction is not only important in the healing process of wounds but is also responsible for stimulating the patient's innate immune system. As a result of the loss of the protective ability of the epidermis, microbes which include bacteria, fungi, and viruses have easier access to the system, which can result in infections. However, the patient is still able to overcome the infections that occur through a cascade of cytokines and growth factors stimulated by inflammation. Long-term inflammation also has negative consequences for the body, which may result in multi-organ failure or lead to fibrosis and scarring of the skin. The innate immune response to burns is not only immediate, but also severe and prolonged, and some people with burn shock may also experience immunosuppression accompanied by an increased susceptibility to fatal infections. This immunosuppression includes apoptosis-induced lymphopenia, decreased interleukin 2 (IL-2) secretion, neutrophil storm, impaired phagocytosis, and decreased monocyte human leukocyte antigen-DR. This is why it is important to understand how the immune system works in people with burns and during infections of wounds by microorganisms. The aim of this study was to characterize the molecular pathways of cell signaling of the immune system of people affected by burns, taking into account the role of microbial infections.
\end{abstract}

Keywords: immune system; burns; microorganism

\section{Introduction}

The skin is the largest organ of the body and constitutes about $16 \%$ of a person's weight. It consists of two layers-a thinner outer layer, i.e., the epidermis, and a deeper, thicker layer, i.e., the dermis. Various other structures are found in the skin, such as hair follicles, sebaceous glands, sweat glands, capillaries, and nerve endings. The main role of the skin is to protect against environmental aggression, such as infections, temperature changes, physical forces, chemicals, etc. In addition, it has immunological, neurosensory and metabolic functions, as well as water homeostasis and thermoregulation. 
A burn is considered to be damage to the skin due to the action of heat, corrosive chemicals, electric current, solar UV rays, radiation (X-ray, UV and other extreme radiation factors), and depending on the degree, the burn can reach deeper tissues or organs [1-3]. The most common are thermal burns, followed by electrical and chemical burns. The most common victims of burns are patients aged 15-64 ( $>60 \%$ of cases) and children up to 4 years of age (20\% of cases) $[1,3,4]$.

Burns are a serious problem. In the United Kingdom, around 250,000 people are burned each year, and there are 300 deaths as a result. Data from the United Kingdom are representative of most developed countries, although some, such as the United States, have a higher incidence of burns [4]. In turn, India experiences over two million burns annually, and this may be a significant underestimation [4]. According to the World Health Organization, there are approximately 300,000 burn deaths annually [2], and according to the American Burn Association data, in America in 2012, the total annual number of burn-related deaths was approximately 3400 [5]. Burns are the third leading cause of death in children aged 5 to 9 [6]. The main cause of death after the first 24 hours is sepsis and the accompanying invasive infection $[1,5,7]$, which is caused by pathogens penetrating the damaged skin that is deprived of its protective function $[2,8]$.

Burns cause several systemic responses: (a) increase in the permeability of capillaries, (b) occurrence of bronchospasms, (c) reduction of the contractility of heart muscle, (d) contraction of the peripheral and visceral vessels, and (e) increase in metabolism up to three times the original rate. There is non-specific downregulation of the immune response, which affects cellular and humoral pathways (Figure 1) [1,4]. The immune response initiates both proinflammatory and anti-inflammatory phases, simultaneously or sequentially, to maintain homeostasis and normal physiology [3]. Thermal damage causes $80 \%$ of leukocyte transcriptome to change, leading to stimulation of innate genes (both proinflammatory and anti-inflammatory) and the suppression of adaptive immune responses [9]. Neutrophil dysfunction, release of immature granulocytes, and a decreased number and disturbed expression of CD14+/HLA-DR+ monocytes have also been observed [10,11]. Conversely, up to 3 years after the burn, there may be a simultaneous increase in the level of granulocyte-macrophage colony stimulating factor (GM-CSF), interleukin 10 (IL-10) and other cytokines [12].

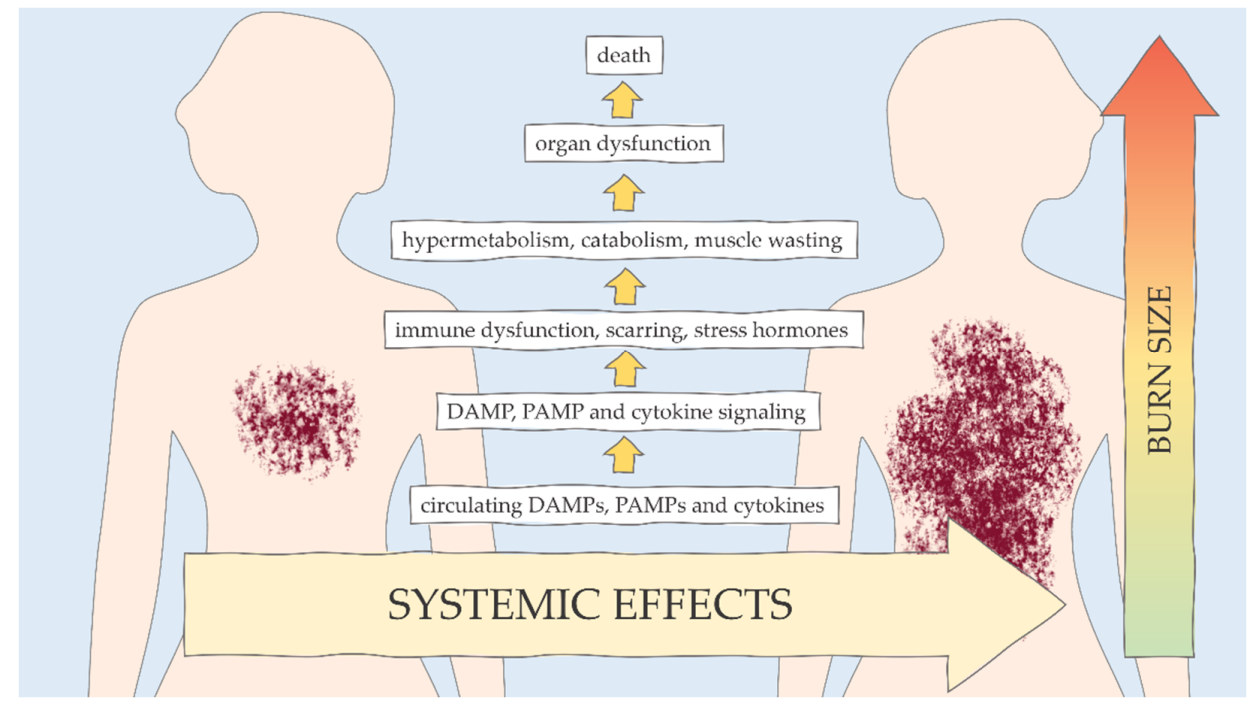

Figure 1. Systemic responses are dependent on the size of the burn (based on [1-4]).

We can distinguish three zones in burns, which were described by Jackson (Figure 2) [13]. The outermost zone is the zone of hyperemia, where tissue perfusion is increased. Tissue here will return to normal over time unless severe sepsis or prolonged hypoperfusion occurs. The middle zone is the zone of ischemia (or stasis), where there is reduced tissue 
perfusion. This area has an increased risk of progressing to necrosis due to hypoperfusion or infection. The inner zone is the zone of coagulation (or necrosis), which occurs at the point of maximum damage and is the area of irreversible cell death because of the coagulation of proteins $[1,4]$. The direction of trauma in burns is usually horizontal, and although it seems that the burn wound should be free of microorganisms because of the high temperature, rapid blisters and the necrosis of damaged tissue open the wound to pathogens, which is associated with the risk of infection [14,15]. Infections in both adults and children with burns include pneumonia, cellulitis and urinary tract infections [16].

In this work, we will review the changes that occur in the immune system of a person who undergoes burns, based on the latest literature data.

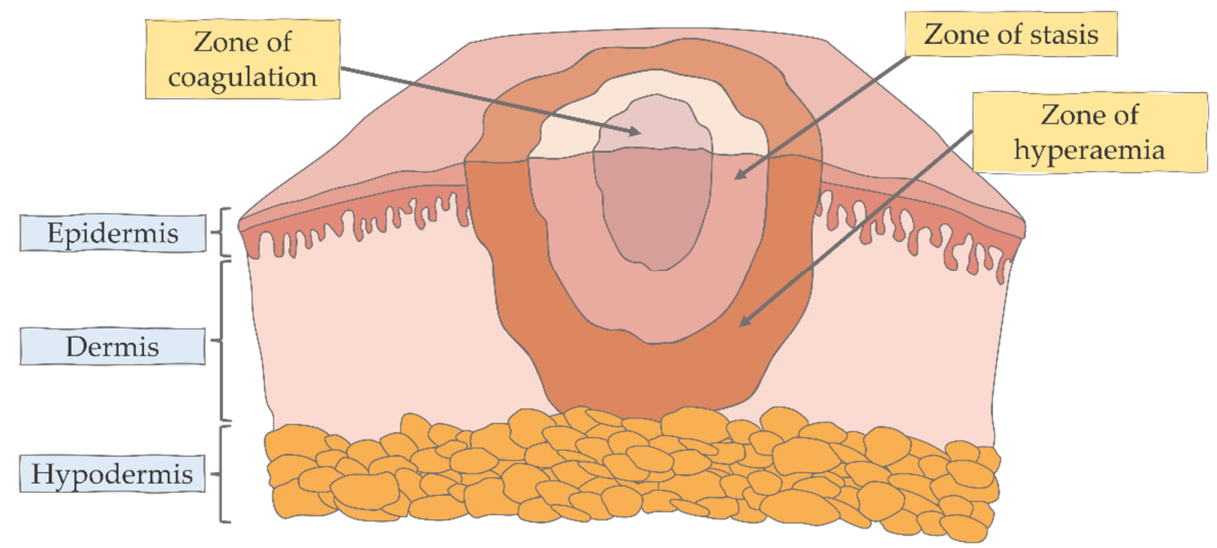

Figure 2. Jackson's three zones in burns.

\section{Host Immune Response to Burns}

At the site of the burn wound, loss of primary tissue is observed as a result of protein denaturation, hence a release into the circulation of toxic proinflammatory mediators and platelet activating factors. Immune cells, similar to macrophages and neutrophils, produce oxygen free radicals (ROS) to destroy pathogens, which damage skin structures, and which results in a strong inflammatory response in the immune system, defined as systemic inflammatory response syndrome (SIRS) [3]. Innate immunity provides non-specific and rapid responses to infection [17], and its mechanisms are the first to respond and recognize microbial pathogen-related molecular patterns (PAMPs) and danger-related molecular patterns (DAMPs). This is achieved using the instrumentation of pattern recognition receptors (PRRs), which include several classes: Toll-like receptors (TLR), NOD-like receptors (NLR), RIG-I-like receptors (RLR) and C-type lectin receptors (CLR) [2,18]. Outside of the body, epithelial cells secrete defensins, lysozymes and cathelicidins, whose roles are to destroy the cell walls of pathogens and provide antibacterial activity [17]. Inside the body, the innate immune system consists of macrophages, neutrophils, dendritic cells (DC) and more. They provide a rapid and non-specific response to commonly known antigens. The activation of these pre-programmed cells occurs when these fragments bind to TLRs on the surface of these immune cells. TLRs also detect common antigenic molecules such as lipoteichoic acids from Gram-positive bacteria and lipopolysaccharides/lipoproteins from Gram-negative bacteria. Binding of PAMP to TLRs leads to rapid phagocytosis of suspect pathogens. In addition, innate immunity involves the recruitment of non-cellular defense mechanisms such as complement, coagulation and proinflammatory cytokine proteins that enhance the acquired immune system [17].

The first cells that respond to burns are mast cells, neutrophils, DCs and monocytes, which migrate to the site of inflammation, initiated by chemotactic factors released from the coagulation process (kallikreins, fibrin peptides) and substances released from mast cells (tumor necrosis factor, histamine, proteases, leukotrienes and cytokines). The cellular response supports phagocytosis and the clearance of necrotic tissue and toxins being released by tissues that have been burned $[3,19,20]$. This is critical because the burn injury 
causes a disruption of the mononuclear phagocyte system (MPS), resulting in a disruption of phagocytosis [21]. In addition to phagocytosis impairment, macrophages also exhibit abnormal intracellular killing actions and chemotaxis [19].

\subsection{Mast Cells}

Mast cells are analogs of basophils in the blood. Mast cells mature in connective tissue and mucous membranes and remain in various tissues for several weeks. The differentiation of these cells occurs depending on the stem cells factor (SCF), also known as the mast cells growth factor (MGF) [22].

Burn injury leads to an increase in the number of mast cells in tissues and subsequently stimulates their degranulation and release of histamine, heparin, and enzymes such as chymase, cathepsin $\mathrm{G}$, and hydroxypeptidase $A[2,14,23,24]$. The substances secreted by MCs promote wound healing, including those caused by burns [25]. Burn injury causes MCs' atrophy, and subsequently, high levels of MCs are observed in burn scar tissue, consistent with their function in promoting wound healing [26] by up to 10-100 times higher than in healthy skin. In rodent models, high levels of cells persist up to 30 days after burn [27].

\subsection{Neutrophils}

In addition to NK and NKT cells, myeloid cells (macrophages, neutrophils, and DCs) that express surface receptors and that activate when stimulated by PAMPs are heavily involved in the immediate immune response [2]. As a result of the immune response, neutrophils produce MMPs, collagenases and elastases, and secrete proinflammatory cytokines. To remove pathogens, neutrophils will use phagolysosomes, free radical release, and antimicrobial proteases that damage cell membranes and trap microbes in histone and DNA networks [14]. Neutrophils can create and release extracellular neutrophil traps (NETs), which are spatial structures made of chromatin fibers with histones and granulocyte granular proteins attached, such as: lysosomal proteases, antibacterial peptides, or proteins responsible for the oxygen inactivation of microorganisms. The structure and biochemical composition of NETs enable efficient trapping and then rapid elimination of pathogens [28].

Neutrophils rapidly infiltrate burn wounds. Hampson et al. [10] reported that, within 24 hours after the injury, the number of neutrophils increases significantly, and the state normalizes 3 days after the injury; then, it increases significantly on day 7 and remains elevated for 28 days after the burn [10]. Neutrophils produce oxidants, antimicrobial peptides and proteolytic enzymes and provide non-specific antimicrobial defense [17]. After the burn, the ability of neutrophils' oxidative burst decreases, which in turn weakens phagocytosis [10,29]; there is a decrease in the speed of motility during chemotaxis [30,31] and decreased bactericidal capacity [14], which ultimately reduce innate immune function. Hampson et al. [10] reported a reduced ex vivo NET generation (followed by a death process-NETosis) in patients with major burns [10]. Jones et al. [32] described a new phenotype of neutrophil migration-spontaneous migration in the absence of chemoattractants that are strongly correlated with the occurrence of sepsis in the burns of patients. These changes were observed 2 days before the development of sepsis, which may prove helpful in post-burn treatment because identification of infections in the blood requires at least 12-24 hours of blood culture before the bacteria reach levels that can be detected [32].

Typically, burns adversely affect neutrophil function by impairing their ability to phagocytize, engage in chemotaxis, produce reactive oxygen species (ROS) and form neutrophil extracellular traps (NETs) [30]. However, this is hazardous, as the antimicrobial properties of neutrophils are primarily based on phagocytosis and the production of ROS and NETs [10]. Impaired chemotaxis in neutrophils is manifested primarily by a reduction in chemotactic distance and a decreased number of chemotactic cells, which results in the inability to reach damaged sites [31]. To prevent inflammation, which can damage tissues adjacent to the burn wound, neutrophil apoptosis is induced by macrophages, and 
then neutrophils are phagocytosed, and the macrophages involved in this process become apoptotic [33].

The high accumulation of neutrophils in various tissues during the early phase of the burn suggests that they may be a source of ROS. ROS production following a severe burn may also cause damage to distant organs [34]. The inflammation that occurs as a result of burn injury is also present in uninjured tissues and makes the body unable to manage on its own in maintaining the balance between ROS production and destruction, causing oxidative stress [35]. ROS produced by neutrophils are one of the mediators and occur in increased amounts in a burn injury [36].

\subsection{Dendritic Cells}

Dendritic cells (DC), also known as dendritic leukocytes (DL), are a family of phagocytes belonging to professional antigen presenting cells (APC). DCs migrate to the lymph nodes to present antigens to CD4 and CD8 T cells in order to initiate an acquired immune response [37,38]. CD103+ DCs present both CD4 and CD8 antigens, and CD11b+ DCs mainly present antigens to CD4 T cells [37].

Patients with burns showed a decrease in the amount of DC, inhibition of myeloidderived DC (mDC) production [20,38], and a reduced ability to induce T-cell activation by LC and DC [38]. Valvis et al. [37] reported a significant increase in the DCs CD8a+ with a decreased activation state after burn. It has been shown that the presence of DC influences the early proliferation of cells occurring 2-3 days after the burn; when there is a loss of DC, it is significantly reduced [20].

\subsection{Monocytes and Macrophages}

Both monocytes and macrophages play an important role in the healing of burns by fostering the production of fibroblasts and keratinocytes [39]. Also, they are classified into classical activated (proinflammatory), non-classical activated (anti-inflammatory) and intermediate cells [40].

Monocytes are primarily responsible for phagocytosis, production of cytokines and antigen presentation [28]. Activated by the injury, monocytes initiate the production of chemokines and cytokines that attract other cells of the immune system, such as, e.g., neutrophils, to the site of injury and enhance their response $[17,28,41]$. Production of cytokines and chemokines are stimulated after monocytes recognize pathogen-associated molecular patterns (PAMPs) and damage-associated molecular patterns (DAMPs) [42] Monocyte migration to the burn site is associated with specific chemoattractants, such as IL-6, IL-8 and IL-8 $\beta$, adenosine and the lymphocyte function-associated antigen-1 (LFA-1) complex [14,43]. Burns increase the number of peripheral blood monocytes [44]. It has been shown that burn patients have fewer monocytes expressing the human leukocyte antigen (HLA-DR), and their number is more reduced in patients with burn sepsis [45,46]. Monocytes leave the bloodstream to reach endangered tissues and become tissue macrophages there $[17,28,41]$.

Macrophages act as significant phagocytes, with the function of direct microbial killing, as do neutrophils. Macrophages include cutaneous (epithelial) Langerhans cells (LC). They are found in tissues exposed to foreign antigens, and when an infection occurs, they secrete cytokines that attract and activate other cells of innate immunity to enhance killing. Their primary function is to regulate $T$ and $B$ cell responses to specific antigens $[17,47]$. In macrophage populations, an initial increase in classical activated is followed by an increase in non-classical activated signaling in the later inflammatory phase [14,38]. Macrophage hyperactivity after burn is associated with changes in intracellular cAMP, the levels of which are increased in immune cells after thermal shock [48]. cAMP is produced by activation of cell surface receptors. They play a role as a second messenger in signal transduction pathways by activating cAMP-dependent kinases (PKA), which leads to the phosphorylation of intracellular proteins [48-50]. According to research conducted by Schwacha et al. [48], in burned animals, cAMP levels in macrophages are increased due 
to the changes that happen in downstream signaling of adenylate cyclase activation and cAMP. Macrophage hyperactivity is also related to a rise in ATP-consuming reactions, such as protein synthesis $(22 \%)$, hepatic gluconeogenesis $(10 \%)$ and cycling of glucose and fatty acids $(21 \%)$. Overall, more than half of the hypermetabolic responses consist of ATP-consuming reactions [51,52].

\subsection{Inflammasomes}

Inflammasomes are multimeric protein complexes that accumulate in the cytosol upon detection of PAMP or DAMP and whose key role is to regulate caspase-1 activation [53]. They are multi-protein complexes composed mainly of protein receptors of the NLR or ALR family, with apoptosis-associated speck-like proteins containing a C-terminal caspase recruitment domain (CARD). The role of NLRP3, NLRC4 and AIM2 inflammasomes in infections and diseases of various backgrounds has been demonstrated [18].

NLRP3 expression is closely associated with patient mortality and has a significant role in the post-burn acute phase [54]. Severe thermal times cause not only inflammation but also metabolic changes. When these are not controlled, severe metabolic dysfunction can occur, during which the NLRP3 inflammasome is stimulated. NLRP3 causes activation of caspase- 1 , which converts pro-IL-1 $\beta$ to its mature form. IL- $1 \beta$ affects metabolic tissues and causes changes in insulin signaling and insulin resistance. These changes often cause stress-induced diabetes in patients with severe burns, which in turn contributes to increased mortality [55]. In addition, NP3R has the capability to identify DAMPs that are released after burn injury [2]. One hour after the burn, a deficiency in NLRP3 expression was observed, leading to a decrease in the expression of factors involved in wound healing processes. Reduced production of proinflammatory cytokines and chemokines impairs not only keratinocyte migration and proliferation, but also chemotaxis of immune cells [56]. It has been reported that NLRP3 is secreted by classically activated macrophages and has a significant role in activating the proliferative healing phase of burn wounds through the release of proinflammatory cytokines, chemokines and growth factors [57]. Conversely, studies by Xiao et al. [58] on rat models showed that NLRP3, secreted mainly by the zone of stasis' macrophages, can negatively affect burn wound healing by producing too many cytokines [56]. Related results have been shown by Han et al. [22], where NLRP3 activity was enhanced at burn onset, and impairment of its activity attenuated the severity of burn-induced acute lung injury (ALI) [22]. Clearly, further studies are needed to determine the exact role of NLRP3 in burn patients.

\subsection{NK and NKT Cells}

NK and NKT cells release cytotoxic granules that attach to infected cells and induce apoptosis. NK cells are activated by type I interferons, and when activated, they induce the synthesis of type II interferons, interferon- $\gamma$ (IFN- $\gamma$ ), tumor necrosis factor- $\alpha$ (TNF- $\alpha)$ [2], perforin and granzymes [17] and present the antigen [59]. They express various receptors, including: NCRs (natural cytotoxicity receptors), belonging to the immunoglobulin family of natural cytotoxicity receptors; KIRs (killer cell immunoglobulin-like receptors), immunoglobulin-like killer cell receptors that interact with class I major histocompatibility complex (MHC) molecules on the surface of NK cells during the transmission of signals that activate or inhibit the activity of these cells; lectin-like receptors, involved in the activation or inhibition of NK cell lectin-like receptors; NK cell activating receptors (including NCR, KAR, NKG2D, -C and -E and Ly49D, -H, -P and -W) and NK cell activity inhibitory receptors (Ly49A, -B, -C, -E, -F, -G, Ly491, NKG2A, -B and IL-T2) [59,60]. NCRs include several major receptors, such as Natural Killer Group 2D (NKG2D), which is not limited to NK cell expression and mediates the recognition of damaged, transformed cells, and Pseudomonas clearance [59].

NK cells, due to their ability to kill without recognizing the histocompatibility complex, constitute one of the first lines of defense against viral infections associated with increased mortality and morbidity after severe thermal injuries [28]. A reduced ability to fight 
Herpes Simplex-1 virus, the most common viral infection affecting burn patients, has been observed $[17,61]$.

NK cell deficiencies are greatest after the first week after burn injury, possibly related to the impairment of the ability to produce IL-2 $[17,28]$, and in severely burned patients, significantly reduced activity persists for 40 days after injury [62].

Patients treated with a standard protocol experience an increase in the number of NK cells 3 weeks after burn injury. Intravenous IgG treatment increases the number of NK cells [63]. Bender et al. [64] showed that administration of polymyxin B to burn patients does not cause a decline in NK cells activity. In addition, endotoxin-rich sera from burn patients showed an inhibitory effect on NK cells [64]. An NK cell activity increase was observed in patients with major burns who were administered anti-CD3 antibody induced activated killer (CD3AK) cells [65]. Klimpeli et al. [61] reported that heat-injured patients have defective NK cell activity against neoplastic cells. It is possible that the failure of NK cell function contributes to an increased cancer rate in the burn patient population [17].

\subsection{Complement System}

The complement system is a central part of the acute phase response (APR) and has a negative impact on the local pathophysiology of a burn wound [66]. Burn wounds cause excessive activation of complement and C-reactive proteins (CRP), which increases the risk of SIRS and adversely affects the healing process of a burn wound $[14,66]$. Since CRP as a marker for SIRS is not practical by its sensitivity and high-level, serum procalcitonin (PCT) was suggested [67]. In patients with burns, high serum levels of CRP persist longer than PCT [68]; thus, the use of PCT allows for a more specific prediction of patient response to treatment. In addition, PCT makes it able to distinguish a patient with a septic burn from a patient with a non-septic burn [69].

Mannose-binding lectin (MBL), a protease mediating the complement lectin pathway, has been shown to play an important role in the host's first line of defense against postburn infectious agents through initiation of the lectin pathway [66]. MBL has been shown to be involved in the spontaneous separation of the scab formed after burn injury. This was confirmed in a study by Møller-Kristensen and co-workers [70] during which it was demonstrated that MBL-null mice had this process inhibited compared to wild-type mice. It is suggested that matrix metalloproteinase (MMP) activities that are involved in scab separation are MBL dependent. This was demonstrated by showing that MBL-null mice had reduced MMP activity in scab skin homogenates [70].

\section{Infections}

There are many factors affecting the body's susceptibility to infections. Size and the deepness of burn injury come first among these factors [71,72]. Colonies of bacteria can be observed naturally in low concentrations-less than $10^{5}$ colony-forming units (CFU), without causing any infection. In the case of burn injury, physical barriers are broken, allowing pathogens access to unprotected soft tissue or circulatory areas [5,73]. Infection is a condition in which the CFU level in the wound exceeds $10^{5}$, and sepsis and discoloration of the burn wound may be present [5]. Because burn wounds do not contain epidermis, they are a suitable site for bacterial growth. The lack of natural protection provided by epidermal cells promotes the development of infection, and as a result, a variety of bacterial flora contaminates the wound surface within hours after the burn [74].

Among the variety of pathogens, some of them are more virulent than others. The more virulent ones release enzymes or use their flagella in order to travel deeper into the burned tissue and disperse to other soft tissues. Because of the absence of host defense, the body cannot tolerate this invasion. Then, these pathogens spread through vascular and lymphatic vessels, which results in bacteremia and sepsis [74-76]. The most prominent causes of sepsis and death include burn wound sepsis and various forms of infections, such as pneumonia, urinary tract infections, or central line catheter infections [72]. 


\subsection{In the Wound}

Burn injuries provide an ideal habitat for opportunistic pathogens to grow and infect tissues [77]. Damaged microbiota and broken skin barriers enable these opportunistic microorganisms to invade the tissue and cause infection [78,79]. High quantities of bacteria indicate the presence of an infection [5].

In the early stages of an injury, Gram-positive infections are more prevalent, whereas Gram-negative bacteria infections become more dominant around 21 days after [17,70]. According to research conducted by Latifi and Karimi [75], Staphylococcus spp. (55.1\%) are the most abundant bacteria found in burn wound cultures, followed by Pseudomonas aeruginosa (14.29\%), Enterococcus sp. (12.24\%), Escherichia coli (4\%), Klebsiella sp. and Proteus sp. (both 2\%). Commensals such as Staphylococcus epidermidis and Propionibacterium acnes present in the burn wound maintain homeostasis, reduce the secretion of proinflammatory cytokines [80] and negatively affect wound healing [81].

Viral burn wound infections and fungal aspergillosis or Candida species can also appear in the wound occasionally. The most common viruses that cause infection are Herpes simplex and Varicella-zoster. Herpes simplex also causes infection when the burned wound is healing [5].

\subsection{Pneumonias}

Pneumonia is a severe infectious respiratory illness that causes inflammation of the pulmonary parenchyma [82]. Inhalation injury induces the risk of infection, causing lower respiratory tract diseases, especially pneumonia $[83,84]$. Burn-related pneumonia is linked to prolonged intubation and mechanical ventilation, and it involves up to $40 \%$ of patients who are intubated. It is the main reason for morbidity and mortality in burn patients $[17,85]$. Liodaki et al. [83] indicated that $22.9 \%$ of burn patients had pneumonia and $10.9 \%$ of them died while they were in Burn Care Unit [83].

Gram-negative rods, especially $P$. aeruginosa, are the major reason for burn-related pneumonia $[5,74]$. Bacteria such as Streptococcus sp. and Haemophilus sp. are naturally occurring organisms in normal flora of the respiratory tract, but after burn injury, they become infectious pathogens that cause pneumonia. Non-native species, such as E. coli, Acinetobacter sp., Fusobacterium sp. and Peptostreptococus sp. are among these pathogens that cause pneumonia [86].

\subsection{In Blood and Urine}

Blood stream infections (BSI) are one of the most dangerous infections that burn patients may have. In order to indicate the BSI, there should be pathogens at least in two blood cultures, or one positive culture, of a patient with sepsis [86,87]. These pathogens, such as diphtheroids, Bacillus sp., Propionibacterium sp., coagulase negative Staphylococci, or micrococci, are not commonly considered as skin pathogens [86]. The fourth most common pathogen isolated from blood cultures in an intensive care unit is Candida albicans. Invasive infection with molds such as Aspergillus is more closely associated with mortality $[5,88]$.

In predisposed burn patients, extended or inappropriate use of urinary catheters enables hematogenous dispersion of bacteria and fungi, which results in urinary tract infections [5]. In this case, urinary catheters should be removed or changed immediately. Gram-negative rods such as Acinetobacter spp., fungi such as Candida spp., and bacteria from Enterobacteriaceae family are the main pathogens isolated from urinary infections $[5,73,89]$.

\subsection{In the Vascular System}

Vascular access devices are required for therapy for the majority of serious burn patients. Because of wound treatment and decreased skin quality, the injury is unable to be dressed with conventional bandages; thus, central venous catheters (CVCs) must be inserted through burnt tissue. These restrictions raise the risk of central line-associated bloodstream infection (CLABSI), yet they are necessary for treatment [73]. Despite their life saving roles, they can become contaminated with pathogens such as yeast, Gram-negative 
bacteria or Gram-positive bacteria. Staphylococcus epidermidis and Staphylococcus aureus are the most frequent bacteria isolated from catheters [5,17]. Catheter-associated infection and septic thrombophlebitis rates in burn patients are as high as $57 \%$ [90,91]. According to the American Burn Association, a central venous catheter should be deemed as the cause of an infection if it is present at any moment in the 48 hours prior to infection, even if it has been removed in the meantime [86].

\section{Cytokines}

Innate immune cells constitute the first line of defense and are involved in recognizing initial threats. They promote the recruitment of additional immune cells through the release of cytokines that bridge the innate and acquired immune systems [92]. Cytokines are small proteins with a molecular weight of 5-20 kDa that function in inflammatory cell signaling [17]. They are produced by nearly every cell to regulate and influence immune response (Figure 3) $[93,94]$. They include interleukins (IL), interferons (INF), tumor necrosis factors (TNF), lymphotoxins (LT), colony-stimulating factors (CSF), chemokines and miscellaneous cytokines [95]. Burn and cell damage can lead to the release of intracellular molecules known as DAMPs [96]. PRRs are present in the host body to recognize DAMPs [97]. Released DAMPs activate the innate immune system by interacting with PRRs to produce proinflammatory cytokines [98]. These cytokines generate a variety of responses. They activate microbicidal functions of immune cells that control or eliminate infections after primary injury. Production of cytokines during severe burns can be excessive, which can cause an overabundance of inflammation. As Bidani and co-workers [99] discovered, in response to stimuli such as smoke inhalation, cytokines cause a hyperactive effect in macrophages. Several established cytokines that contribute to burn immune responses are detailed below.
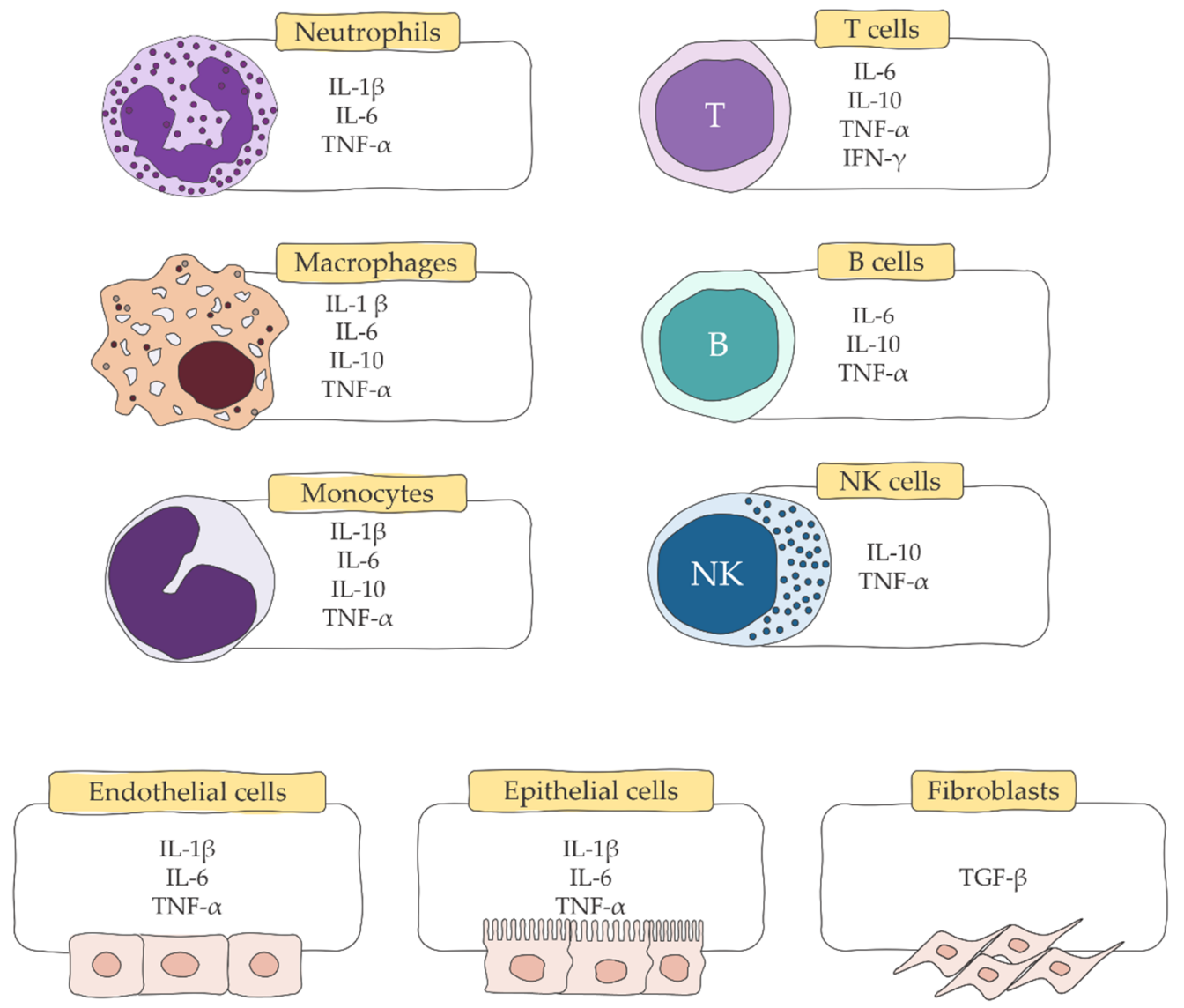

Figure 3. Schematic representation of cells involved in the immune response expressing different cytokines. Abbreviations: IL, interleukin; TNF, tumor necrosis factor; IFN, interferon; TGF, transforming growth factor; NK, natural killer (based on $[93,94]$ ). 


\subsection{Proinflammatory Responses}

\subsubsection{IL-1}

The family of IL-1, through its control of many innate immune processes, is a major regulator of inflammation [100]. IL-1 has a wide range of biological functions, which include acting as a leukocytic pyrogen, a mediator of fever and a leukocytic endogenous mediator, and an inducer of several components of the acute-phase response and lymphocyte-activating factor (LAF) [101,102]. In burn injuries, increased levels of IL-1 $\beta$ have been reported in patients during the first week after injury [103,104]. Kupper and co-workers [104] suggest that the source of IL-1 $\beta$ activity is the injured keratinocyte. The release of IL-1 $\beta$ from the wound into the systemic circulation accounts in part for the metabolic changes that include temperature elevation, skeletal muscle proteolysis, and alterations in the production of certain serum proteins by the hepatocyte. Furthermore, epidermal IL-1 $\beta$ released from damaged tissues is also a potent T-cell chemoattractant; thus, it is suspected that burn wound IL- $1 \beta$ may affect sequestration of $T$ cells near the burn wound, resulting in T cell lymphopenia [17]. In addition, IL-1 $\beta$ participates not only in extracellular matrix remodeling, but also in fibrogenesis. It is overexpressed in the early inflammatory phase of normal wound healing but is also increased in impaired wound repair and fibrosis $[105,106]$. This makes IL-1 $\beta$ one of the cytokines that has been shown to be a predictor of the presence of hypertrophic scarring after burns [17].

\subsubsection{IL-6}

Macrophages play an important role in the initial phase of the inflammatory response, particularly mediated by their production of proinflammatory cytokines, including IL-6 [14]. It has been reported that during a burn, macrophages are hyperactive and have an increased capacity for the production of proinflammatory mediators. This was confirmed by the results of studies, where an increased level of IL-6 was detected in burn patients [48]. The highest level of IL- 6 in the plasma of burn patients was within 6 hours after burn injury. The levels of IL-6 have been shown to be proportional to the size of the burn, and persistently high levels of IL-6 post burn injury may be indicative of both the severity of the burn and likelihood of mortality [106]. IL-6 is one of the most consistently elevated inflammatory mediators in burn patients, and its high levels on the first day after injury increase the risk of developing sepsis [107]. Gauglitz and co-workers [108] observed that pediatric burn patients with inhalation injury have a greater risk for mortality if IL-6 levels are increased early after injury. Qiao et al. [109] confirmed these results in trauma patients and in experimental models of sepsis, where early detection of high IL-6 is predictive of multiple organ dysfunction syndrome and mortality [109].

\subsection{3. $\mathrm{TNF}-\alpha$}

TNF- $\alpha$ is one of the proinflammatory cytokines secreted by macrophages and lymphocytes in response to cell damage caused by infection or malignant transformation. It can also be generated from other type of cells and tissues, e.g., adipocytes [110]. Its main role is regulation of immune cells that generate the acute phase reaction to burn injuries. It has been shown that human TNF is able to conduct the complex orchestration of events leading to the inflammatory response [111,112]. It causes the release of IL-1 and IL-6, thus enhancing the non-specific immune response to sepsis, burn injury or inhalation injury [17]. TNF also increases vasodilation and capillary permeability by raising the level of nitric oxide in immune and endothelial cells [17]. It helps to fight systemic infections by promoting IL-1, which drives the fever response in the hypothalamus. TNF- $\alpha$ may play an important role in prognosis after burn injury. It was observed that impaired TNF response correlated with deceased survival in elderly burn patients [113]. Moreover, TNF- $\alpha$ contributes to immune hyper-responsiveness after burns and tissue destruction and increases the cachectic response through IL-1 and IL-6. It acts as the most potent catabolic cytokine. Torre-Amione et al. [114] showed that, through IL-1, it increases apoptosis in liver, muscle, and fat cells, which can lead to myocardial depression in critically ill patients. 


\subsubsection{IFN- $\gamma$}

IFN- $\gamma$, or immune IFN, is primarily produced by $\mathrm{T}$ lymphocytes in response to antigens or mitogens [95]. It is the earliest detectable cytokine at the site of immunization with protein antigens and plays a crucial role in the activation of innate and adaptive responses to bacteria $[17,95]$. IFN- $\gamma$ also enhances expression of MHC class II on antigen-presenting cells, leading to more efficient antigen presentation [60]. Increased levels of IFN- $\gamma$ are observed in burns initially, but they resolve over time [115]. It is unknown as of now if the immunosuppression observed after burn injury is due to reduced IFN- $\gamma$ activity. In addition, decreased T-cell proliferation and impaired ability to produce IFN- $\gamma$ have been observed in burn patients $[116,117]$. It is suspected that the reduced immune response in fighting burn infection may be related to reduced IFN- $\gamma$ production [115].

\subsection{Anti-Inflammatory Responses}

4.2.1. IL-10

IL-10 is known as a major immunoregulatory cytokine, mainly produced by T-cells and monocytes [118]. It has originally been called "cytokine synthesis inhibitory factor" (CSIF) because of its inhibitory effects on the release of cytokines such as IFN- $\gamma$, TNF- $\alpha$, and IL-1, -6 , and -8 [119]. Dehne and co-workers [119] noticed higher amounts of IL-10 in patients a short time after burn injury. However, the role of IL-10 in the initiation of immunodepression after major trauma remains controversial. Researchers reported that patients with higher levels of IL-10 were more likely to have incidence of septic events [120,121]. Thus, the immunosuppressive effects of IL-10 may be due to the suppression of acquired immune responses by IL-10 [17].

\subsubsection{TGF- $\beta$}

Transforming growth factor-beta (TGF- $\beta$ ) is another well-known anti-inflammatory cytokine. It has four isoforms (TGF $\beta 1$, TGF $\beta 2$, TGF $\beta 3$, and TGF $\beta 4$ ), which play an important role in preventing auto-immune conditions and resolving primary immune responses. Three of them (TGF- $\beta 1,-\beta 2,-\beta 3$ ) are secreted as inactive latent precursors that require activation prior to binding to the TGF- $\beta$ receptors [122]. They share $60-80 \%$ homology and appear to be present in wound healing, including in wounds from early human fetuses, which repair cutaneous wounds perfectly $[123,124]$. However, isoforms in fetal wounds differ in levels of expression, duration in the wound and biological activity [125]. Wang and co-workers [126] suggested a possible role for TGF- $\beta 1$ in hypertrophic scar formation. They showed that hypertrophic-derived fibroblasts and hypertrophic scar tissue produced more mRNA and proteins for TGF- $\beta 1$ than normal skin or fibroblasts derived from normal skin. Moreover, it was also demonstrated that hypertrophic-derived fibroblasts have increased expression of TGF- $\beta 1$ receptors compared with normal skin [127]. Schmid and co-workers [127] suggested that this expression of TGF- $\beta 1$ is persistent compared to normal wound healing. Most likely, this persistence of receptor expression may cause a fibrotic phenotype. In addition, TGF- $\beta 1$ has been shown to modulate immune function in the body, which causes an antiproliferative effect on B and T lymphocytes. It inhibits the transition of B cells from the G1 phase to the S phase of the cell cycle, which is the reason for the inhibition of proliferation [128]. TGF also causes a class change in antibodies to IgA and an overall reduction in the secretion of most Ig by inhibiting mRNA induction [129]. Ishikawa et al. [130] showed that TGF- $\beta 1$ is involved in the suppression of humoral immunity after burn injury. Their results show significantly higher TGF mRNA expression in the spleen and liver of mice after burn injury. Additionally, they showed that the impaired production of IgM and IgG is caused by TGF's inhibition of the proliferation of cells secreting these immunoglobulins. However, TGF- $\beta 1$ does not impair the production of IgM and IgG by cells. 


\section{Antioxidant and Trace Element Supplementation}

Treatment of burns is difficult because it must affect both the intensity of the proinflammatory and anti-inflammatory response [2]. However, the main goal of treatment is to reduce inflammation and improve patient prognosis. Numerous studies on this topic have already contributed to reduced mortality and more effective stabilization of patients, but the topic still faces difficulties. As of today, therapies that focus on specifically blocking cytokines such as IL-1, TNF or IL-6 have been found to be ineffective [42]. For this reason, the focus has been on other strategies to reduce the inflammation and hypermetabolism associated with burn injury. One option to improve clinical outcomes is supplementation with antioxidants (e.g., ascorbic acid, glutathione, acetylcysteine, or vitamins A, E, and C) and trace elements [39]. The use of this strategy scavenges free radicals, inhibits the formation of new ones, and through these actions, reduces inflammation and hypermetabolism in patients after burn injury [51]. Antioxidants are a key component of mechanisms that reduce the formation of reactive oxygen species and attenuate the synthesis of transcription factors such as NF- $\mathrm{kB}$ contributing to reduced inflammation [52]. Literature reports indicate not only the positive effects of antioxidants on the survival of burn patients, but also on faster wound healing [131,132]. A study by Rehou et al. [42] showed that burn patients had better outcomes after supplementation with antioxidants and trace elements. Patients had reduced levels of cytokines such as IL- $1 \beta$ and IFN- $\gamma$, but there were no differences in IL-6 levels. Caffeic acid phenethyl ester (CAPE) has also shown strong antioxidant properties. As an anti-inflammatory, antiviral, antimicrobial, and immunostimulant, it is effective in the treatment of burn injury, which was confirmed in rat models [133]. Another interesting compound with antioxidant properties is melatonin, which not only contributes to the reduction of oxidative stress but also shows protective effects in burn-induced skin damage and appears to be a promising agent for inhibiting the activation of blood coagulation after severe burns $[134,135]$.

\section{Conclusions}

Innate immunity plays a key role after burn injury. When physical barriers are broken, pathogens have access to unprotected soft tissue or circulatory areas. In this case, cells of the innate immune system are an essential part of the organism's protection. Proinflammatory cytokines, produced by cells, activate microbicidal functions that control or eliminate infections after primary injury. However, the inflammatory responses are coupled to counter regulatory mechanisms, and in severe burn injuries, patients can easily be overwhelmed by both anti-inflammatory and inflammatory mechanisms. During severe burns, patients are also at risk of secondary infections because wounds are suitable for bacterial growth. Such phenomena are dangerous and can cause immunosuppression. The acquired knowledge of the immune system, nonspecific innate mechanisms, protein signaling networks of complement, coagulation and cytokines have contributed to the increased survival of burn patients over several decades. In addition, research into the therapeutic options for patients after burn injury is contributing to improved clinical outcomes. Antioxidants that reduce inflammation and hypermetabolism appear to be a promising method to reduce patient mortality. However, not all mechanisms occurring within the body of individuals with burn injuries have been understood or explained thus far. Further research and their elucidation may provide the most effective tools to optimize immune function after burn injury.

Funding: This work was supported by research grants DS495 and DS640 of the Medical University of Lublin.

Institutional Review Board Statement: Not applicable.

Informed Consent Statement: Not applicable.

Data Availability Statement: Not applicable.

Conflicts of Interest: The authors declare no conflict of interest. 


\section{References}

1. Schaefer, T.J.; Tannan, S.C. Thermal Burns. In StatPearls [Internet]; StatPearls Publishing: Treasure Island, FL, USA, 2021. Available online: https:/ / www.ncbi.nlm.nih.gov /books/NBK430773/ (accessed on 4 November 2021).

2. Boldeanu, L.; Boldeanu, M.V.; Bogdan, M.; Meca, A.D.; Coman, C.G.; Buca, B.R.; Tartau, C.G.; Tartau, L.M. Immunological Approaches and Therapy in Burns (Review). Exp. Ther. Med. 2020, 20, 2361-2367. [CrossRef] [PubMed]

3. Rani, M.; Schwacha, M.G. Aging and the Pathogenic Response to Burn. Aging Dis 2012, 3, 171-180. [PubMed]

4. Hettiaratchy, S.; Dziewulski, P. ABC of Burns: Pathophysiology and Types of Burns. BMJ 2004, 328, 1427-1429. [CrossRef] [PubMed]

5. Norbury, W.; Herndon, D.N.; Tanksley, J.; Jeschke, M.G.; Finnerty, C.C. Infection in Burns. Surg. Infect. (Larchmt.) 2016, 17, 250-255. [CrossRef] [PubMed]

6. Lee, C.J.; Mahendraraj, K.; Houng, A.; Marano, M.; Petrone, S.; Lee, R.; Chamberlain, R.S. Pediatric Burns: A Single Institution Retrospective Review of Incidence, Etiology, and Outcomes in 2273 Burn Patients (1995-2013). J. Burn. Care Res. 2016, 37, e579-e585. [CrossRef]

7. Williams, F.N.; Herndon, D.N.; Hawkins, H.K.; Lee, J.O.; Cox, R.A.; Kulp, G.A.; Finnerty, C.C.; Chinkes, D.L.; Jeschke, M.G. The Leading Causes of Death after Burn Injury in a Single Pediatric Burn Center. Crit. Care 2009, 13, R183. [CrossRef]

8. Joshi, A.P.; Saad, M.; Mohan, M. A Review on Burn and Burn Models in Animals. J. Basic Pharmacol. Toxicol. 2017, 1, 1-8.

9. Xiao, W.; Mindrinos, M.N.; Seok, J.; Cuschieri, J.; Cuenca, A.G.; Gao, H.; Hayden, D.L.; Hennessy, L.; Moore, E.E.; Minei, J.P.; et al. A Genomic Storm in Critically Injured Humans. J. Exp. Med. 2011, 208, 2581-2590. [CrossRef] [PubMed]

10. Hampson, P.; Dinsdale, R.J.; Wearn, C.M.; Bamford, A.L.; Bishop, J.R.B.; Hazeldine, J.; Moiemen, N.S.; Harrison, P.; Lord, J.M. Neutrophil Dysfunction, Immature Granulocytes, and Cell-Free DNA are Early Biomarkers of Sepsis in Burn-Injured Patients: A Prospective Observational Cohort Study. Ann. Surg. 2017, 265, 1241-1249. [CrossRef]

11. Jeschke, M.G.; Patsouris, D.; Stanojcic, M.; Abdullahi, A.; Rehou, S.; Pinto, R.; Chen, P.; Burnett, M.; Amini-Nik, S. Pathophysiologic Response to Burns in the Elderly. EBioMedicine 2015, 2, 1536-1548. [CrossRef]

12. Al-Tarrah, K.; Hewison, M.; Moiemen, N.; Lord, J.M. Vitamin D Status and Its Influence on Outcomes Following Major Burn Injury and Critical Illness. Burns Trauma 2018, 6, 11. [CrossRef] [PubMed]

13. Jackson, D.M. The diagnosis of the depth of burning. Br. J. Surg. 1953, 40, 588-596. [CrossRef] [PubMed]

14. Strudwick, X.L.; Cowin, A.J. The Role of the Inflammatory Response in Burn Injury; IntechOpen: London, UK, 2017; ISBN 978-178923-131-1.

15. Rendon, J.L.; Choudhry, M.A. Th17 Cells: Critical Mediators of Host Responses to Burn Injury and Sepsis. J. Leukoc. Biol. 2012, 92, 529-538. [CrossRef] [PubMed]

16. American Burn Association, National Burn Repository. American Burn Association National Burn Repository 2016 Report; Report of data from 2006-2015; American Burn Association, National Burn Repository: Chicago, IL, USA, 2016.

17. Blears, E.; Sommerhalder, C.; Toliver-Kinsky, T.; Finnerty, C.C.; Herndon, D.N. Current Problems in Burn Immunology. Curr. Probl. Surg. 2020, 57, 100779. [CrossRef] [PubMed]

18. Niedźwiedzka-Rystwej, P.; Ratajczak, W.; Tokarz-Deptuła, B.; Deptuła, W. Charakterystyka i rola inflamasomów. Post Biol. Kom. 2016, 43, 237-254.

19. Tiwari, V.K. Burn Wound: How It Differs from Other Wounds? Indian J. Plast. Surg. 2012, 45, 364-373. [CrossRef]

20. Vinish, M.; Cui, W.; Stafford, E.; Bae, L.; Hawkins, H.; Cox, R.; Toliver-Kinsky, T. Dendritic Cells Modulate Burn Wound Healing by Enhancing Early Proliferation. Wound Repair Regen. 2016, 24, 6-13. [CrossRef] [PubMed]

21. Xiu, F.; Jeschke, M.G. Perturbed Mononuclear Phagocyte System in Severely Burned and Septic Patients. Shock 2013, 40, 81-88. [CrossRef]

22. Han, S.; Cai, W.; Yang, X.; Jia, Y.; Zheng, Z.; Wang, H.; Li, J.; Li, Y.; Gao, J.; Fan, L.; et al. ROS-Mediated NLRP3 Inflammasome Activity Is Essential for Burn-Induced Acute Lung Injury. Mediat. Inflamm. 2015, 2015, e720457. [CrossRef]

23. Niedzwiedzka, P.; Deptula, W. Rola komorek tucznych w odpowiedzi immunologicznej. Medycyna Weterynaryjna 2008, 64, 1291-1294.

24. Barrett, L.W.; Fear, V.S.; Waithman, J.C.; Wood, F.M.; Fear, M.W. Understanding Acute Burn Injury as a Chronic Disease. Burns Trauma 2019, 7, s41038-019-0163-2. [CrossRef] [PubMed]

25. Dong, X.; Xu, T.; Ma, S.; Wen, H. Expression and Activity Levels of Chymase in Mast Cells of Burn Wound Tissues Increase during the Healing Process in a Hamster Model. Exp. Ther. Med. 2015, 9, 2190-2194. [CrossRef]

26. Souza, H.R.; de Azevedo, L.R.; Possebon, L.; de Souza Costa, S.; Iyomasa-Pilon, M.M.; Oliani, S.M.; Girol, A.P. Heterogeneity of Mast Cells and Expression of Annexin A1 Protein in a Second Degree Burn Model with Silver Sulfadiazine Treatment. PLoS One 2017, 12, e0173417. [CrossRef]

27. Lateef, Z.; Stuart, G.; Jones, N.; Mercer, A.; Fleming, S.; Wise, L. The Cutaneous Inflammatory Response to Thermal Burn Injury in a Murine Model. Int. J. Mol. Sci. 2019, 20, 538. [CrossRef] [PubMed]

28. Devine, R.A.; Diltz, Z.; Hall, M.W.; Thakkar, R.K. The Systemic Immune Response to Pediatric Thermal Injury. Int. J. Burns Trauma 2018, 8, 6-16.

29. Calum, H.; Moser, C.; Jensen, P.Ø.; Christophersen, L.; Maling, D.S.; Van Gennip, M.; Bjarnsholt, T.; Hougen, H.P.; Givskov, M.; Jacobsen, G.K.; et al. Thermal Injury Induces Impaired Function in Polymorphonuclear Neutrophil Granulocytes and Reduced Control of Burn Wound Infection. Clin. Exp. Immunol. 2009, 156, 102-110. [CrossRef] 
30. Hazeldine, J.; McGee, K.C.; Al-Tarrah, K.; Hassouna, T.; Patel, K.; Imran, R.; Bishop, J.R.B.; Bamford, A.; Barnes, D.; Wilson, Y.; et al. Multicentre, Longitudinal, Observational Cohort Study to Examine the Relationship between Neutrophil Function and Sepsis in Adults and Children with Severe Thermal Injuries: A Protocol for the Scientific Investigation of the Biological Pathways Following Thermal Injury-2 (SIFTI-2) Study. BMJ Open 2021, 11, e052035. [CrossRef] [PubMed]

31. Yang, Y.; Liu, L.; Guo, Z.; Li, L.; Shao, Y.; Song, M.; Sun, B. Investigation and Assessment of Neutrophil Dysfunction Early after Severe Burn Injury. Burns 2021, 47, 1851-1862. [CrossRef] [PubMed]

32. Jones, C.N.; Moore, M.; Dimisko, L.; Alexander, A.; Ibrahim, A.; Hassell, B.A.; Warren, H.S.; Tompkins, R.G.; Fagan, S.P.; Irimia, D. Spontaneous Neutrophil Migration Patterns during Sepsis after Major Burns. PLoS One 2014, 9, e114509. [CrossRef]

33. Chen, Z.-C.; Wu, S.-Y.S.; Su, W.-Y.; Lin, Y.-C.; Lee, Y.-H.; Wu, W.-H.; Chen, C.-H.; Wen, Z.-H. Anti-Inflammatory and Burn Injury Wound Healing Properties of the Shell of Haliotis Diversicolor. BMC Complementary Altern. Med. 2016, 16, 487. [CrossRef]

34. Gürbüz, V.; Corak, A.; Yeğen, B.C.; Kurtel, H.; Alican, I. Oxidative Organ Damage in a Rat Model of Thermal Injury: The Effect of Cyclosporin A. Burns 1997, 23, 37-42. [CrossRef]

35. Parihar, A.; Parihar, M.S.; Milner, S.; Bhat, S. Oxidative Stress and Anti-Oxidative Mobilization in Burn Injury. Burns 2008, 34, 6-17. [CrossRef] [PubMed]

36. Kartchner, L.B.; Gode, C.J.; Dunn, J.L.M.; Glenn, L.I.; Duncan, D.N.; Wolfgang, M.C.; Cairns, B.A.; Maile, R. One-Hit Wonder: Late after Burn Injury, Granulocytes Can Clear One Bacterial Infection but Cannot Control a Subsequent Infection. Burns 2019, 45, 627-640. [CrossRef]

37. Valvis, S.M.; Waithman, J.; Wood, F.M.; Fear, M.W.; Fear, V.S. The Immune Response to Skin Trauma Is Dependent on the Etiology of Injury in a Mouse Model of Burn and Excision. J. Invest. Dermatol. 2015, 135, 2119-2128. [CrossRef]

38. van den Berg, L.M.; de Jong, M.A.W.P.; de Witte, L.; Ulrich, M.M.W.; Geijtenbeek, T.B.H. Burn Injury Suppresses Human Dermal Dendritic Cell and Langerhans Cell Function. Cell Immunol. 2011, 268, 29-36. [CrossRef]

39. Kurmis, R.; Greenwood, J.; Aromataris, E. Trace Element Supplementation Following Severe Burn Injury: A Systematic Review and Meta-Analysis. J. Burn Care Res. 2016, 37, 143-159. [CrossRef] [PubMed]

40. Merah-Mourah, F.; Cohen, S.O.; Charron, D.; Mooney, N.; Haziot, A. Identification of Novel Human Monocyte Subsets and Evidence for Phenotypic Groups Defined by Interindividual Variations of Expression of Adhesion Molecules. Sci. Rep. 2020, 10, 4397. [CrossRef] [PubMed]

41. Galbraith, N.J.; Gardner, S.A.; Walker, S.P.; Trainor, P.; Carter, J.V.; Bishop, C.; Sarojini, H.; O’Brien, S.J.; Bhatnagar, A.; Polk, H.C.; et al. The Role and Function of I $\kappa \mathrm{K} \alpha / \beta$ in Monocyte Impairment. Sci. Rep. 2020, 10, 12222. [CrossRef]

42. Rehou, S.; Shahrokhi, S.; Natanson, R.; Stanojcic, M.; Jeschke, M.G. Antioxidant and Trace Element Supplementation Reduce the Inflammatory Response in Critically Ill Burn Patients. J. Burn Care Res. 2018, 39, 1-9. [CrossRef]

43. Strudwick, X.L.; Adams, D.H.; Pyne, N.T.; Samuel, M.S.; Murray, R.Z.; Cowin, A.J. Systemic Delivery of Anti-Integrin AL Antibodies Reduces Early Macrophage Recruitment, Inflammation, and Scar Formation in Murine Burn Wounds. Adv. Wound Care 2020, 9, 637-648. [CrossRef]

44. Williams, K.N.; Szilagyi, A.; He, L.-K.; Conrad, P.; Halerz, M.; Gamelli, R.L.; Shankar, R.; Muthumalaiappan, K. Dendritic Cell Depletion in Burn Patients Is Regulated by MafB Expression. J. Burn Care Res. 2012, 33, 747-758. [CrossRef] [PubMed]

45. Yang, H.-M.; Yu, Y.; Chai, J.-K.; Hu, S.; Sheng, Z.-Y.; Yao, Y.-M. Low HLA-DR Expression on CD14+ Monocytes of Burn Victims with Sepsis, and the Effect of Carbachol in Vitro. Burns 2008, 34, 1158-1162. [CrossRef] [PubMed]

46. Venet, F.; Tissot, S.; Debard, A.-L.; Faudot, C.; Crampé, C.; Pachot, A.; Ayala, A.; Monneret, G. Decreased Monocyte Human Leukocyte Antigen-DR Expression after Severe Burn Injury: Correlation with Severity and Secondary Septic Shock. Crit. Care Med. 2007, 35, 1910-1917. [CrossRef]

47. Kaczmarczyk, M.; Niedźwiedzka, P.; Deptuła, W. Characteristics of Dendritic Cells. Adv. Clin. Exp. Med. 2006, 15, 871.

48. Schwacha, M.G. Macrophages and Post-Burn Immune Dysfunction. Burns 2003, 29, 1-14. [CrossRef]

49. Grbic, J.T.; Mannick, J.A.; Gough, D.B.; Rodrick, M.L. The Role of Prostaglandin E2 in Immune Suppression Following Injury. Ann. Surg. 1991, 214, 253-263. [CrossRef]

50. Horgan, A.F.; O'Riordain, D.S.; Chin, D.H.; Mannick, J.A.; Rodrick, M.L. The Role of Cyclic Adenosine Monophosphate in the Suppression of Cellular Immunity after Thermal Injury. Arch. Surg. 1994, 129, 1284-1289. [CrossRef] [PubMed]

51. Horton, J.W. Free Radicals and Lipid Peroxidation Mediated Injury in Burn Trauma: The Role of Antioxidant Therapy. Toxicology 2003, 189, 75-88. [CrossRef]

52. Reddell, L.; Cotton, B.A. Antioxidants and Micronutrient Supplementation in Trauma Patients. Curr. Opin. Clin. Nutr. Metab. Care 2012, 15, 181-187. [CrossRef]

53. Guo, H.; Callaway, J.B.; Ting, J.P.-Y. Inflammasomes: Mechanism of Action, Role in Disease, and Therapeutics. Nat. Med. 2015, 21, 677-687. [CrossRef]

54. Schwacha, M.G.; Samy, T.S.; Catania, R.A.; Chaudry, I.H. Thermal Injury Alters Macrophage Responses to Prostaglandin E2: Contribution to the Enhancement of Inducible Nitric Oxide Synthase Activity. J. Leukoc. Biol. 1998, 64, 740-746. [CrossRef] [PubMed]

55. Stanojcic, M.; Chen, P.; Harrison, R.A.; Wang, V.; Antonyshyn, J.; Zúñiga-Pflücker, J.C.; Jeschke, M.G. Leukocyte Infiltration and Activation of the NLRP3 Inflammasome in White Adipose Tissue Following Thermal Injury. Crit. Care Med. 2014, 42, 1357-1364. [CrossRef] 
56. Vinaik, R.; Abdullahi, A.; Barayan, D.; Jeschke, M.G. NLRP3 Inflammasome Activity Is Required for Wound Healing after Burns. Transl. Res. 2020, 217, 47-60. [CrossRef] [PubMed]

57. Cuddihy, J.; Wu, G.; Ho, L.; Kudo, H.; Dannhorn, A.; Mandalia, S.; Collins, D.; Weir, J.; Spencer, A.; Vizcaychipi, M.; et al. Lactate Dehydrogenase Activity Staining Demonstrates Time-Dependent Immune Cell Infiltration in Human Ex-Vivo Burn-Injured Skin. Sci. Rep. 2021, 11, 21249. [CrossRef]

58. Xiao, M.; Li, L.; Li, C.; Liu, L.; Yu, Y.; Ma, L. 3,4-Methylenedioxy- $\beta$-Nitrostyrene Ameliorates Experimental Burn Wound Progression by Inhibiting the NLRP3 Inflammasome Activation. Plast. Reconstr. Surg. 2016, 137, 566e. [CrossRef] [PubMed]

59. Farag, S.S.; Fehniger, T.A.; Ruggeri, L.; Velardi, A.; Caligiuri, M.A. Natural Killer Cell Receptors: New Biology and Insights into the Graft-versus-Leukemia Effect. Blood 2002, 100, 1935-1947. [CrossRef]

60. Tosi, M.F. Innate Immune Responses to Infection. J. Allergy Clin. Immunol. 2005, 116, 241-249. [CrossRef]

61. Klimpel, G.R.; Herndon, D.N.; Fons, M.; Albrecht, T.; Asuncion, M.T.; Chin, R.; Stein, M.D. Defective NK Cell Activity Following Thermal Injury. Clin. Exp. Immunol. 1986, 66, 384-392.

62. Blazar, B.A.; Rodrick, M.L.; O’Mahony, J.B.; Wood, J.J.; Bessey, P.Q.; Wilmore, D.W.; Mannick, J.A. Suppression of Natural Killer-Cell Function in Humans Following Thermal and Traumatic Injury. J. Clin. Immunol. 1986, 6, 26-36. [CrossRef]

63. Dibirdik, I.; Durak, N.; Kişlaoğlu, E.; Kutluay, T.; Aytemiz, C. Effects of Prophylactic Intravenous Immunoglobulin-G Therapy on Humoral and Cellular Immune Components and Their Functions in Burned Patients. Burns 1995, 21, 130-135. [CrossRef]

64. Bender, B.S.; Winchurch, R.A.; Thupari, J.N.; Proust, J.J.; Adler, W.H.; Munster, A.M. Depressed Natural Killer Cell Function in Thermally Injured Adults: Successful in Vivo and in Vitro Immunomodulation and the Role of Endotoxin. Clin. Exp. Immunol. $1988,71,120-125$.

65. Zhan, J.; Li, G. A study on the effects of CD3AK cells on the improvement of cellular immune function in burned patients. Zhonghua Shao Shang Za Zhi = Zhonghua Shaoshang Zazhi = Chin. J. Burn. 2001, 17, 159-162.

66. Korkmaz, H.I.; Krijnen, P.A.J.; Ulrich, M.M.W.; de Jong, E.; van Zuijlen, P.P.M.; Niessen, H.W.M. The Role of Complement in the Acute Phase Response after Burns. Burns 2017, 43, 1390-1399. [CrossRef]

67. Mokline, A.; Garsallah, L.; Rahmani, I.; Jerbi, K.; Oueslati, H.; Tlaili, S.; Hammouda, R.; Gasri, B.; Messadi, A.A. Procalcitonin: A Diagnostic and Prognostic Biomarker of Sepsis in Burned Patients. Ann. Burns Fire Disasters 2015, 28, 116-120.

68. Sinha, A.; Sharma, M.K.; Tripathi, K.; Duggal, N.; Tiwari, V.K. Evaluation of Serum Levels of Procalcitonin and C-Reactive Protein as Prognostic Indicators in Burns. Indian J. Plast. Surg. 2021, 54, 308-313. [CrossRef]

69. Zbyrak, V.; Reverón, S.L.; Smoke, S.; Mehta, A.; Marano, M.A.; Lee, R. Antibiotic Usage After Procalcitonin-Guided Therapy Algorithm Implementation In A Burn Intensive Care Unit. Ann. Burns Fire Disasters 2020, 33, 317-321. [PubMed]

70. Møller-Kristensen, M.; Hamblin, M.R.; Thiel, S.; Jensenius, J.C.; Takahashi, K. Burn Injury Reveals Altered Phenotype in Mannan-Binding Lectin-Deficient Mice. J. Investig. Dermatol. 2007, 127, 1524-1531. [CrossRef]

71. Brownson, E.G.; Gibran, N.S. Evaluation of the Burn Wound: Management Decisions. In Total Burn Care; Elsevier: Amsterdam, The Netherlands, 2018; pp. 87-92.

72. Church, D.; Elsayed, S.; Reid, O.; Winston, B.; Lindsay, R. Burn Wound Infections. Clin. Microbiol. Rev. 2006, 19, 403-434. [CrossRef]

73. Cambiaso-Daniel, J.; Gallagher, J.J.; Norbury, W.B.; Finnerty, C.C.; Herndon, D.N.; Culnan, D.M. Treatment of Infection in Burn Patients. In Total Burn Care; Elsevier: Amsterdam, The Netherlands, 2018; pp. 93-113.e4. [CrossRef]

74. Essayagh, T.; El Hamzaoui, S. Epidemiology of burn wound infection in Rabat, Morocco: Three-year review. Med. Sante Trop. 2014, 24, 157-164. [CrossRef] [PubMed]

75. Latifi, N.A.; Karimi, H. Correlation of Occurrence of Infection in Burn Patients. Ann. Burns Fire Disasters 2017, 30, 172-176. [PubMed]

76. Sewunet, T.; Demissie, Y.; Mihret, A.; Abebe, T. Bacterial Profile and Antimicrobial Susceptibility Pattern of Isolates among Burn Patients at Yekatit 12 Hospital Burn Center, Addis Ababa, Ethiopia. Ethiop. J. Health Sci. 2013, 23, 209-216. [CrossRef] [PubMed]

77. Patil, N.K.; Luan, L.; Bohannon, J.K.; Hernandez, A.; Guo, Y.; Sherwood, E.R. Frontline Science: Anti-PD-L1 Protects against Infection with Common Bacterial Pathogens after Burn Injury. J. Leukoc. Biol. 2018, 103, 23-33. [CrossRef] [PubMed]

78. Sanford, J.A.; Gallo, R.L. Functions of the Skin Microbiota in Health and Disease. Semin Immunol. 2013, 25, 370-377. [CrossRef] [PubMed]

79. Toliver-Kinsky, T.; Kobayashi, M.; Suzuki, F.; Sherwood, R.E. The systemic inflammatory response syndrome. In Total Burn Care; Elsevier: Amsterdam, The Netherlands, 2018; pp. 205-220.

80. Plichta, J.K.; Gao, X.; Lin, H.; Dong, Q.; Toh, E.; Nelson, D.E.; Gamelli, R.L.; Grice, E.A.; Radek, K.A. Cutaneous Burn Injury Promotes Shifts in the Bacterial Microbiome in Autologous Donor Skin: Implications for Skin Grafting Outcomes. Shock 2017, 48, 441-448. [CrossRef]

81. Corcione, S.; Lupia, T.; De Rosa, F.G. Microbiome in the Setting of Burn Patients: Implications for Infections and Clinical Outcomes. Burns Trauma 2020, 8, tkaa033. [CrossRef]

82. Chan, C.-H.; Yang, S.-F.; Yeh, H.-W.; Yeh, Y.-T.; Wang, Y.-H.; Teng, Y.-H.; Yeh, C.-B. Risk of Pneumonia in Patients with Burn Injury: A Population-Based Cohort Study. Clin. Epidemiol. 2018, 10, 1083-1091. [CrossRef]

83. Liodaki, E.; Kalousis, K.; Mauss, K.L.; Kisch, T.; Mailaender, P.; Stang, F. Epidemiology of Pneumonia in a Burn Care Unit: The Influence of Inhalation Trauma on Pneumonia and of Pneumonia on Burn Mortality. Ann. Burns Fire Disasters 2015, 28, 128-133. [PubMed] 
84. Woodson, L.C.; Sherwood, E.R.; Kinsky, M.P.; Talon, M.; Martinello, C.; Woodson, S.M. Anesthesia for burned patients. In Total Burn Care; Elsevier: Amsterdam, The Netherlands, 2018; pp. 131-157.

85. de La Cal, M.A.; Cerdá, E.; García-Hierro, P.; Lorente, L.; Sánchez-Concheiro, M.; Díaz, C.; van Saene, H.K. Pneumonia in Patients with Severe Burns : A Classification According to the Concept of the Carrier State. Chest 2001, 119, 1160-1165. [CrossRef]

86. Greenhalgh, D.G.; Saffle, J.R.; Holmes, J.H.; Gamelli, R.L.; Palmieri, T.L.; Horton, J.W.; Tompkins, R.G.; Traber, D.L.; Mozingo, D.W.; Deitch, E.A.; et al. American Burn Association Consensus Conference to Define Sepsis and Infection in Burns. J. Burn. Care Res. 2007, 28, 776-790. [CrossRef] [PubMed]

87. Liao, P.-H.; Kao, C.-C.; How, C.-K.; Yang, Y.-S.; Chen, M.-C.; Hung-Tsang Yen, D.; Lee, Y.-T. Initial White Blood Cell Count and Revised Baux Score Predict Subsequent Bloodstream Infection in Burn Patients: A Retrospective Analysis of Severe Burn Patients from the Formosa Color Dust Explosion of 2015. J. Formos Med. Assoc. 2021, 120, 1719-1728. [CrossRef] [PubMed]

88. Wisplinghoff, H.; Bischoff, T.; Tallent, S.M.; Seifert, H.; Wenzel, R.P.; Edmond, M.B. Nosocomial Bloodstream Infections in US Hospitals: Analysis of 24,179 Cases from a Prospective Nationwide Surveillance Study. Clin. Infect. Dis. 2004, $39,309-317$. [CrossRef]

89. Ballard, J.; Edelman, L.; Saffle, J.; Sheridan, R.; Kagan, R.; Bracco, D.; Cancio, L.; Cairns, B.; Baker, R.; Fillari, P.; et al. Positive Fungal Cultures in Burn Patients: A Multicenter Review. J. Burn. Care Res. 2008, 29, 213-221. [CrossRef]

90. O'Neill, J.A.; Pruitt, B.A.; Foley, F.D.; Moncrief, J.A. Suppurative Thrombophlebitis-a Lethal Complication of Intravenous Therapy. J. Trauma 1968, 8, 256-267. [CrossRef]

91. Samsoondar, W.; Freeman, J.B.; Coultish, I.; Oxley, C. Colonization of Intravascular Catheters in the Intensive Care Unit. Am. J. Surg. 1985, 149, 730-732. [CrossRef]

92. Land, W.G. The Role of Damage-Associated Molecular Patterns in Human Diseases: Part I - Promoting Inflammation and Immunity. Sultan. Qaboos Univ. Med. J. 2015, 15, e9-e21. [PubMed]

93. Kany, S.; Vollrath, J.T.; Relja, B. Cytokines in Inflammatory Disease. Int. J. Mol. Sci. 2019, 20, 6008. [CrossRef] [PubMed]

94. Takeuchi, O.; Akira, S. Pattern Recognition Receptors and Inflammation. Cell 2010, 140, 805-820. [CrossRef]

95. Curfs, J.H.; Meis, J.F.; Hoogkamp-Korstanje, J.A. A Primer on Cytokines: Sources, Receptors, Effects, and Inducers. Clin. Microbiol. Rev. 1997, 10, 742-780. [CrossRef]

96. Rani, M.; Nicholson, S.E.; Zhang, Q.; Schwacha, M.G. Damage-Associated Molecular Patterns (DAMPs) Released after Burn Are Associated with Inflammation and Monocyte Activation. Burns 2017, 43, 297-303. [CrossRef]

97. Kaneko, N.; Kurata, M.; Yamamoto, T.; Morikawa, S.; Masumoto, J. The Role of Interleukin-1 in General Pathology. Inflamm. Regen. 2019, 39, 12. [CrossRef]

98. Roh, J.S.; Sohn, D.H. Damage-Associated Molecular Patterns in Inflammatory Diseases. Immune. Netw. 2018, 18, e27. [CrossRef]

99. Bidani, A.; Wang, C.Z.; Heming, T.A. Early Effects of Smoke Inhalation on Alveolar Macrophage Functions. Burns 1996, 22, 101-106. [CrossRef]

100. Gery, I.; Gershon, R.K.; Waksman, B.H. Potentiation of the T-Lymphocyte Response to Mitogens. I. The Responding Cell. J. Exp. Med. 1972, 136, 128-142. [CrossRef]

101. Rosenstreich, D.L.; Vogel, S.N.; Jacques, A.R.; Wahl, L.M.; Oppenheim, J.J. Macrophage Sensitivity to Endotoxin: Genetic Control by a Single Codominant Gene. J. Immunol. 1978, 121, 1664-1670.

102. Cannon, J.G.; Friedberg, J.S.; Gelfand, J.A.; Tompkins, R.G.; Burke, J.F.; Dinarello, C.A. Circulating Interleukin-1 Beta and Tumor Necrosis Factor-Alpha Concentrations after Burn Injury in Humans. Crit. Care Med. 1992, 20, 1414-1419. [CrossRef]

103. Finnerty, C.C.; Herndon, D.N.; Przkora, R.; Pereira, C.T.; Oliveira, H.M.; Queiroz, D.M.M.; Rocha, A.M.C.; Jeschke, M.G. Cytokine Expression Profile over Time in Severely Burned Pediatric Patients. Shock 2006, 26, 13-19. [CrossRef]

104. Kupper, T.S.; Ballard, D.W.; Chua, A.O.; McGuire, J.S.; Flood, P.M.; Horowitz, M.C.; Langdon, R.; Lightfoot, L.; Gubler, U. Human Keratinocytes Contain MRNA Indistinguishable from Monocyte Interleukin 1 Alpha and Beta MRNA. Keratinocyte Epidermal Cell-Derived Thymocyte-Activating Factor Is Identical to Interleukin 1. J. Exp. Med. 1986, 164, 2095-2100. [CrossRef]

105. Salgado, R.M.; Alcántara, L.; Mendoza-Rodríguez, C.A.; Cerbón, M.; Hidalgo-González, C.; Mercadillo, P.; Moreno, L.M.; Álvarez-Jiménez, R.; Krötzsch, E. Post-Burn Hypertrophic Scars Are Characterized by High Levels of IL-1 $\beta$ MRNA and Protein and TNF- $\alpha$ Type i Receptors. Burns 2012, 38, 668-676. [CrossRef]

106. Ueyama, M.; Maruyama, I.; Osame, M.; Sawada, Y. Marked Increase in Plasma Interleukin-6 in Burn Patients. J. Lab Clin. Med. 1992, 120, 693-698.

107. Pileri, D.; Accardo Palombo, A.; D’Amelio, L.; D'Arpa, N.; Amato, G.; Masellis, A.; Cataldo, V.; Mogavero, R.; Napoli, B.; Lombardo, C.; et al. Concentrations of Cytokines Il-6 and Il-10 in Plasma of Burn Patients: Their Relationship to Sepsis and Outcome. Ann. Burns Fire Disasters 2008, 21, 182-185.

108. Gauglitz, G.G.; Finnerty, C.C.; Herndon, D.N.; Mlcak, R.P.; Jeschke, M.G. Are Serum Cytokines Early Predictors for the Outcome of Burn Patients with Inhalation Injuries Who Do Not Survive? Critical. Care 2008, 12, R81. [CrossRef]

109. Qiao, Z.; Wang, W.; Yin, L.; Luo, P.; Greven, J.; Horst, K.; Hildebrand, F. Using IL-6 Concentrations in the First 24 h Following Trauma to Predict Immunological Complications and Mortality in Trauma Patients: A Meta-Analysis. Eur. J. Trauma Emerg. Surg. 2018, 44, 679-687. [CrossRef]

110. Popko, K.; Gorska, E.; Stelmaszczyk-Emmel, A.; Plywaczewski, R.; Stoklosa, A.; Gorecka, D.; Pyrzak, B.; Demkow, U. Proinflammatory Cytokines IL-6 and TNF- $\alpha$ and the Development of Inflammation in Obese Subjects. Eur. J. Med. Res. 2010, 15, 120-122. [CrossRef] 
111. Old, L.J. Tumor Necrosis Factor (TNF). Science 1985, 230, 630-632. [CrossRef]

112. Spooner, C.E.; Markowitz, N.P.; Saravolatz, L.D. The Role of Tumor Necrosis Factor in Sepsis. Clin. Immunol. Immunopathol. 1992, 62, S11-S17. [CrossRef]

113. Stanojcic, M.; Chen, P.; Xiu, F.; Jeschke, M.G. Impaired Immune Response in Elderly Burn Patients: New Insights Into the Immune-Senescence Phenotype. Ann. Surg. 2016, 264, 195-202. [CrossRef]

114. Torre-Amione, G.; Bozkurt, B.; Deswal, A.; Mann, D.L. An Overview of Tumor Necrosis Factor Alpha and the Failing Human Heart. Curr. Opin. Cardiol. 1999, 14, 206-210. [CrossRef]

115. Marchi, L.F.; Sesti-Costa, R.; Ignacchiti, M.D.C.; Chedraoui-Silva, S.; Mantovani, B. In Vitro Activation of Mouse Neutrophils by Recombinant Human Interferon-Gamma: Increased Phagocytosis and Release of Reactive Oxygen Species and pro-Inflammatory Cytokines. Int. Immunopharmacol. 2014, 18, 228-235. [CrossRef]

116. O'Sullivan, S.T.; Lederer, J.A.; Horgan, A.F.; Chin, D.H.; Mannick, J.A.; Rodrick, M.L. Major Injury Leads to Predominance of the T Helper-2 Lymphocyte Phenotype and Diminished Interleukin-12 Production Associated with Decreased Resistance to Infection. Ann. Surg. 1995, 222, 482-490; discussion 490-492. [CrossRef]

117. Wolf, S.E.; Woodside, K.J.; Ramirez, R.J.; Kobayashi, M.; Suzuki, F.; Herndon, D.N. Insulin-like Growth Factor-I/Insulin-like Growth Factor Binding Protein-3 Alters Lymphocyte Responsiveness Following Severe Burn. J. Surg. Res. 2004, 117, $255-261$. [CrossRef]

118. Katsikis, P.D.; Chu, C.Q.; Brennan, F.M.; Maini, R.N.; Feldmann, M. Immunoregulatory Role of Interleukin 10 in Rheumatoid Arthritis. J. Exp. Med. 1994, 179, 1517-1527. [CrossRef] [PubMed]

119. Dehne, M.G.; Sablotzki, A.; Hoffmann, A.; Mühling, J.; Dietrich, F.E.; Hempelmann, G. Alterations of Acute Phase Reaction and Cytokine Production in Patients Following Severe Burn Injury. Burns 2002, 28, 535-542. [CrossRef]

120. Sherry, R.M.; Cue, J.I.; Goddard, J.K.; Parramore, J.B.; DiPiro, J.T. Interleukin-10 Is Associated with the Development of Sepsis in Trauma Patients. J. Trauma Inj. Infect. Crit. Care 1996, 40, 613-617; discussion 616-617. [CrossRef]

121. Lyons, A.; Kelly, J.L.; Rodrick, M.L.; Mannick, J.A.; Lederer, J.A. Major Injury Induces Increased Production of Interleukin-10 by Cells of the Immune System with a Negative Impact on Resistance to Infection. Ann. Surg. 1997, 226, 450-458; discussion 458-460. [CrossRef]

122. Klass, B.R.; Grobbelaar, A.O.; Rolfe, K.J. Transforming Growth Factor B1 Signalling, Wound Healing and Repair: A Multifunctional Cytokine with Clinical Implications for Wound Repair, a Delicate Balance. Postgrad. Med. J. 2009, 85, 9-14. [CrossRef] [PubMed]

123. Roberts, A.B.; Sporn, M.B. Differential Expression of the TGF-Beta Isoforms in Embryogenesis Suggests Specific Roles in Developing and Adult Tissues. Mol. Reprod. Dev. 1992, 32, 91-98. [CrossRef]

124. Cowin, A.J.; Holmes, T.M.; Brosnan, P.; Ferguson, M.W. Expression of TGF-Beta and Its Receptors in Murine Fetal and Adult Dermal Wounds. Eur. J. Dermatol. 2001, 11, 424-431.

125. Penn, J.W.; Grobbelaar, A.O.; Rolfe, K.J. The Role of the TGF- $\beta$ Family in Wound Healing, Burns and Scarring: A Review. Int. J. Burns Trauma 2012, 2, 18-28.

126. Wang, R.; Ghahary, A.; Shen, Q.; Scott, P.G.; Roy, K.; Tredget, E.E. Hypertrophic Scar Tissues and Fibroblasts Produce More Transforming Growth Factor-Beta1 MRNA and Protein than Normal Skin and Cells. Wound Repair Regen. 2000, 8, 128-137. [CrossRef]

127. Schmid, P.; Itin, P.; Cherry, G.; Bi, C.; Cox, D.A. Enhanced Expression of Transforming Growth Factor-Beta Type I and Type II Receptors in Wound Granulation Tissue and Hypertrophic Scar. Am. J. Pathol. 1998, 152, 485-493. [PubMed]

128. Smeland, E.B.; Blomhoff, H.K.; Holte, H.; Ruud, E.; Beiske, K.; Funderud, S.; Godal, T.; Ohlsson, R. Transforming Growth Factor Type Beta (TGF Beta) Inhibits G1 to S Transition, but Not Activation of Human B Lymphocytes. Exp. Cell Res. 1987, 171, $213-222$. [CrossRef]

129. Stavnezer, J. Regulation of Antibody Production and Class Switching by TGF-Beta. J. Immunol. 1995, 155, 1647-1651.

130. Ishikawa, K.; Nishimura, T.; DeSerres, S.; Meyer, A.A. The Effects of Transforming Growth Factor-Beta Neutralization on Postburn Humoral Immunity. J. Trauma 2004, 57, 529-536. [CrossRef] [PubMed]

131. van Zanten, A.R.H.; Dhaliwal, R.; Garrel, D.; Heyland, D.K. Enteral Glutamine Supplementation in Critically Ill Patients: A Systematic Review and Meta-Analysis. Crit. Care 2015, 19, 294. [CrossRef]

132. Rowan, M.P.; Cancio, L.C.; Elster, E.A.; Burmeister, D.M.; Rose, L.F.; Natesan, S.; Chan, R.K.; Christy, R.J.; Chung, K.K. Burn Wound Healing and Treatment: Review and Advancements. Crit. Care 2015, 19, 243. [CrossRef]

133. Hoşnuter, M.; Gürel, A.; Babucçu, O.; Armutcu, F.; Kargi, E.; Işikdemir, A. The Effect of CAPE on Lipid Peroxidation and Nitric Oxide Levels in the Plasma of Rats Following Thermal Injury. Burns 2004, 30, 121-125. [CrossRef]

134. Mayo, J.C.; Tan, D.-X.; Sainz, R.M.; Lopez-Burillo, S.; Reiter, R.J. Oxidative Damage to Catalase Induced by Peroxyl Radicals: Functional Protection by Melatonin and Other Antioxidants. Free Radic. Res. 2003, 37, 543-553. [CrossRef] [PubMed]

135. Tunali, T.; Sener, G.; Yarat, A.; Emekli, N. Melatonin Reduces Oxidative Damage to Skin and Normalizes Blood Coagulation in a Rat Model of Thermal Injury. Life Sci. 2005, 76, 1259-1265. [CrossRef] 